\title{
EVALUATION OF ACARICIDAL ACTIVITY OF PURPUREOCILLIUM LILACINUM ISOLATED FROM EGYPTIAN SOIL AGAINST TETRANYCHUS URTICAE
}

\author{
Mohamed A. Nawar ${ }^{1}$, Amany A. Abo-Elnasr ${ }^{2}$, Abdel Nasser A. \\ Kobisi $^{1}$ and Gohyza A. Hefnawy ${ }^{{ }^{*}}$ \\ ${ }^{1}$ Department of Plant Protection, Desert Research Center, El- \\ Matareya, Cairo, Egypt \\ ${ }^{2}$ Department of Botany and Microbiology, Faculty of Science, Helwan \\ University, Egypt. \\ "E-mail: gohyzahefnawy@yahoo.com
}

$\mathrm{T}$ he study is aimed to isolate and identify a potential entomopathogenic fungus from fields infested with spider mites and evaluate them as a bio-rationale agent against Tetranychus urticae Koch., which is an important agricultural pest that infests horticultural crops in both field and greenhouses. Macroscopic and microscopic characteristics showed that the obtained entomogenous isolate was Purpureocillium lilacinum (formerly, Paecilomyces lilacinus). P. Lilacinum demonstrated mortality rates on adult females of $T$. urticae of 71.19 and $77.97 \%$ with conidial concentrations of $5 \times 10^{7}$ and $1.6 \times 10^{8}$, respectively, 10 days after application. Median lethal concentration of $P$. lilacinum was $2.85 \times 10^{6}$ conidia/ml. Enzymatic activity of $P$. lilacinum was evaluated. In this context, chitinolytic activity of $P$. lilacinum was relatively weak, since the clear halo obtained was only $4.43 \mathrm{~mm}$ in diameter. The activity of chitinase enzyme insignificantly increased over the incubation period of 10 days. In contrast, proteolytic activity of $P$. lilacinum was high and showed a clear zone $(25.8 \mathrm{~mm})$ around the colony after 10 days. So, it is concluded that $P$. lilacinum has a potential biological control against $T$. urticae. Finally, evaluation of the ethyl acetate extract of $P$. lilacinum showed acaricidal potency since it exhibited $\mathrm{LC}_{50}$ values of $10.49 \mathrm{mg} / \mathrm{ml}$ for eggs and $30.75 \mathrm{mg} / \mathrm{ml}$ for adults. So, it is concluded that $P$. lilacinum has a potential biological control against T. urticae.

Keywords: Paecilomyces lilacinus, two spotted spider mite, biological control, secondary metabolites 
Family Tetranychidae comprises many species of phytophagous spider mites that usually occupy the lower surface of plant leaves and feed by piercing plant cell to suck out the cell sap. Hence, they cause severe damage to plants. Among them, Tetranychus urticae Koch. can invade more than 150 plant species of fruits, vegetables and ornamentals (Fasulo and Denmark, 2000). Feeding of spider mites results in chlorosis, leaves may turn to yellow, leaves shed and eventually, the whole plant collapse especially at high infestation rate (Smith, 1996). Chemical acaricides have been successfully used to control T. urticae (Attia et al., 2013). However, pesticides resistance is rapidly developed because of the short lifecycle, rapid reproduction and plentiful offspring of spider mites (Van Leeuwen et al., 2010). The problems of resistance as well as the ecological pollution caused by synthetic pesticides, there is an urgent need for sustainable and eco-friendly management methods.

Different types of biological control agents have been screened and assessed against spider mites. In this context, predator mites such as Phytoseiulus persimilis Athias-Henriot (Acari: Phytoseiidae) that specifically feeds on Tetranychus sp. as well as Neoseiulus californicus (Acari: Phytoseiidae) are effective way to control spider mites (Attia et al., 2013). Studies demonstrated the strong acaricidal potency of plant extracts and essential oils on spider mites. The methanol extract of Cleome gynandra, Capsicum frutescence and Urtica dioica highly reduced $T$. urticae population (Kapsoot et al., 2013). Eucalyptus oils rich in cineole showed potent acaricidal activity against $T$. urticae (Choi et al., 2004). Microorganisms are another group of biocontrol agent that showed high efficacy in spider mites control. For example, thuringiensin produced by $B$. thuringiensisis showed potent acaricidal efficacy on Tetranychus urticae, $T$. cinnabarinus (Neal et al., 1987) and Panonychus ulmi (Vargas, 1993). Pseudomonas fluorescens exhibited a strong efficacy on adults of Oligonychus coffeae under laboratory conditions (Roobakkumar et al., 2011). Abamectin (avermectin) produced from Streptomyces avermitilis demonstrated the high toxic effect of on $T$. cinnabarinus ( $\mathrm{Wu}$ and Liu, 1997), T. urticae, Phyllocoptruta oleivora, Panonychus citri and T. turkestani (Putter et al., 1981).

One of the most studied organisms with respect of biological control of spider mites is entomopathogenic fungi (EPF). Fifty-six genera comprise about 750 fungal species are known as arthropod pathogens (Hawksworth et al., 1995). Naturally, EPF play an important role in management of spider mite populations. Consequently, they can be used separately as an alternative to synthetic pesticides or in combination with other ways of control in an integrated mite management program (Maniania et al., 2008). Among EPF, several species, e.g. Hirsutella thompsonii and Neozygites floridana are called acaripathogenic fungi, since they exclusively infect members of Acari while the other entomogenous fungi species kill both insects as well as acari

Egyptian J. Desert Res., 68, No. 2, 157-172 (2018) 
(Chandler et al., 2000). Some fungi such as Beauvaria bassiana, Metarhizium anisopliae and Lecanicellium lecanii have been screened against spider mites and exhibit acricidal potential; therefore, they could be exploited to develop bio-rationale acaricides (Gatarayiha, 2010).

This study is aimed to isolate potential entomogenous fungal isolates from the rhizosphere of plants infested with spider mites, examine the effectiveness of the obtained isolate/s on adult females of $T$. urticae under laboratory conditions, identification of this isolate/s and finally, evaluation of the virulence factors of this isolate, for instance its ability to produce chitinase and protease enzymes.

\section{MATERIAL AND METHODS}

\section{Collection of Soil Samples}

Seventeen soil samples were collected from the rhizosphere of infested plants from six different fields at El-Khatatba at Alexadria governorate, Egypt. Samples were collected at 10-15 cm under soil surface using sterilized spatula then they were placed individually in sterilized polyethelene bags and then investigated in Department of Plant Protection at Desert Research Centre.

\section{Isolation of Entomopathogenic Fungi by Insect Bait Method}

Isolation of entomogenous fungi was done by using the insect bait technique developed by Zimmermann (1986) (Fig.1). Soil samples were sieved to remove any debris and placed in sterilized plastic cups with perforated lids. Five larvae of the wax moth, Galleria mellonella, (Lepidoptera: Pyralidae) were immersed in water bath at $56^{\circ} \mathrm{C}$ to prevent webbing, then placed on the surface of each soil sample. The cups containing larvae were inverted upside down and incubated at $25^{\circ} \mathrm{C}$ for two weeks. After the first week, cups were checked for dead larvae daily. The cadavers of larvae were collected, and surface sterilized with $1 \%$ sodium hypochlorite for 30 seconds, then rinsed twice with sterilized distilled water prior to incubation in moist chamber (which is sterilized petri dish with moistened filter paper) at $28^{\circ} \mathrm{C}$ for 7 days. The cadavers showing fungal growth were transferred to potato dextrose agar (PDA) plates supplemented with chloramphenicol and incubated at $28^{\circ} \mathrm{C}$ for 7 days.

\section{Morphological Identification of the Entomogenous Fungus}

Cultures were grown on Czapek's yeast extract agar and incubated at $28^{\circ} \mathrm{C}$ for 7-10 days. Identification of the emtomopathogenic isolate was done on morphological basis using culture characteristics e.g. growth rate, color, pigmentation as well as microscopic features e.g. conidiophores and conidia (Luangsa-ard et al., 2011). The results are confirmed by Mycological Centre, Assiut University, Egypt. 


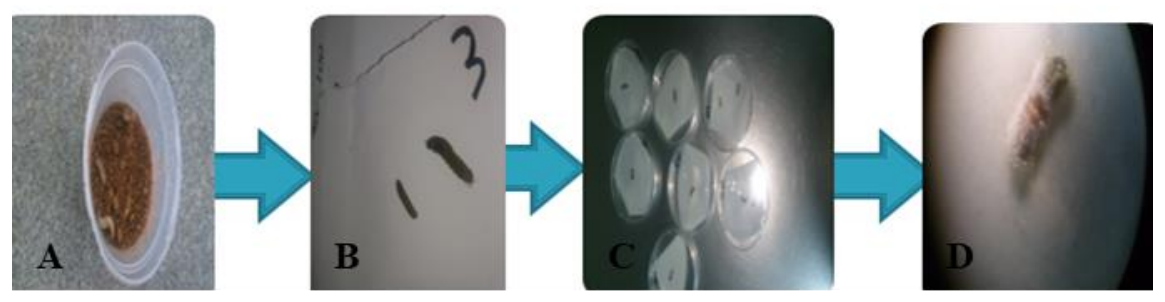

Fig. (1). Steps of baiting technique for isolation of entomopathogenic fungi. A. Larvae of G. mellonella in soil sample. B. Dead larvae. C. Dead larvae incubated in moist chamber. D. fungal hyphae emerging from dead larvae under dissecting microscope.

\section{Effect of Purpureocillium lilacinum on Spider Mites \\ 4.1. Preparation of conidial suspension}

One entomopathogenic fungus (EPF) was isolated from soil by using baiting technique. The isolate was cultured on PDA plate $(11 \mathrm{~cm})$ and incubated at $28 \pm 2^{\circ} \mathrm{C}$ for 15 days, conidia were harvested by scrapping the surface of the plate and suspend it in $20 \mathrm{ml}$ of sterilized distilled water with $0.05 \%$ tween 80 , the suspension was vortexed for 3-5 min to produce a homogenous suspension then it was filtered through sterilized muslin cloth in $250 \mathrm{ml}$ conical flask containing $80 \mathrm{ml}$ of sterilized distilled water. Four concentrations of $8 \times 10^{5}, 2.6 \times 10^{6}, 5 \times 10^{7}$ and $1.6 \times 10^{8}$ conidia/ml were prepared using haemocytometer in conidial count.

\subsection{Bioassay of conidial suspension against $T$. urticae}

Conidial suspension was assayed against adult females of $T$. urticae as follows: $250 \mu \mathrm{l}$ were placed on the surface of mulberry leaf disc $25 \mathrm{~mm}$ in diameter and let to dry for 30-45 min then ten adult females of spider mite were transferred to each replicate by using fine hair paint brush. Three replicates were used for each conidial concentration and distilled water with $0.05 \%$ tween 80 was used as control. Mortality rates were recorded at the $7^{\text {th }}$ and the $10^{\text {th }}$ day after application and corrected according to Abbott formula (Abbott, 1925).

\section{Enzyme Activity of $P$. lilacinum}

\subsection{Screening for chitinolytic activity of $P$. lilacinum}

Chitinolytic activity of $P$. lilacinum was determined by plate assay method. Colloidal chitin was prepared from purified chitin (Qulikems) according to the method developed by Roberts and Selitrennikoff (1988), with few modifications described by Al-Ahmadi et al. (2008), Colloidal chitin is prepared as follows: chitin $(5 \mathrm{~g})$ were digested in $90 \mathrm{ml}$ of concentrated $\mathrm{HCl}$ and mixed gently on magnetic stirrer for $2 \mathrm{~h}, 500 \mathrm{ml}$ of ice-cold ethyl alcohol were added then stirred for $30 \mathrm{~min}$, the digested chitin

Egyptian J. Desert Res., 68, No. 2, 157-172 (2018) 
then incubated for $24 \mathrm{~h}$ at $28^{\circ} \mathrm{C}$. A dense precipitate is obtained following centrifugation at $2000 \mathrm{rpm}, 4^{\circ} \mathrm{C}$ for $15 \mathrm{~min}$, the colloidal chitin was washed repeatedly with distilled water and $\mathrm{pH}$ was adjusted to 7 . Chitinase assay medium in which chitin employed as a sole carbon source prepared as follows: Colloidal chitin ( $1 \% \mathrm{w} / \mathrm{v}), 6 \mathrm{~g}$ of $\mathrm{Na}_{2} \mathrm{HPO}_{4}, 1.0 \mathrm{~g}$ of $\mathrm{NH}_{4} \mathrm{Cl}, 3.0 \mathrm{~g}$ of $\mathrm{KH}_{2} \mathrm{PO}_{4}, 0.5 \mathrm{~g}$ of $\mathrm{NaCl}, 0.05 \mathrm{~g}$ of $15 \mathrm{~g}$ of agar, and $\mathrm{pH}$ was adjusted to 8 and then autoclaved at $121^{\circ} \mathrm{C}$ for $15 \mathrm{~min}$ (Kuddus and Ahmad, 2013). After cooling the medium was poured into Petri plates and allowed to solidify. The fresh culture plugs of $P$. lilacinum was inoculated onto the medium and incubated at $28^{\circ} \mathrm{C}$ for 10 days under observation to detect clear zone formation around fungal colony. Enzymatic activity was measured by the following formula: $\mathrm{EA}=\mathrm{D}-\mathrm{d}$; (D) diameter of colony plus clear zone; (d) diameter of colony (Hasan et al., 2013).

\subsection{Screening for proteolytic activity of $P$. lilacinum:}

For proteolytic activity, $1.5 \%(\mathrm{w} / \mathrm{v})$ of skimmed milk was autoclaved separately at $121^{\circ} \mathrm{C}$ for $10 \mathrm{~min}$. Nutrient agar medium (Oxoid, Basingstoke, Hampshire, England) $13 \mathrm{~g} / \mathrm{L}$ is autoclaved at $121^{\circ} \mathrm{C}$ for $15 \mathrm{~min}$. After cooling, the sterilized skimmed milk was added to the medium and poured into Petri plates and allowed to solidify. The fresh culture plugs of $P$. lilacinum was inoculated onto the medium and incubated at $28^{\circ} \mathrm{C}$ for 10 days and observed for the clear zone formation. Enzymatic activity was measured by the following formula: $E A=D-d$; (D) diameter of colony plus clear zone; (d) diameter of colony.

\section{Effect of Crude Extract of P. lilacinum on Adult and Eggs of $T$. urticae}

Twelve plugs $(10 \mathrm{~mm})$ of fresh $P$. lilacinum culture were inoculated into $300 \mathrm{ml}$ of Potato dextrose broth medium (dextrose $(20 \mathrm{~g} / \mathrm{L})$ and potato extract of 200 g potato) and incubated at $28^{\circ} \mathrm{C}$ for 10 days at $150 \mathrm{rpm}$. After incubation time, culture was filtered, centrifuged and subjected to extraction with ethyl acetate (1:1) three times. Ethyl acetate extract was dried under vacuum, weighed and four concentrations were prepared $5,10,20,30 \mathrm{mg} / \mathrm{ml}$ using ethanol as solvent. The prepared concentrations were assayed against T. urticae. For adulticidal assay, three leaf discs $(25 \mathrm{~mm})$ were dipped in each concentration, dried at room temperature and twenty adult females were transferred to each disc by fine hair brush. Mortality rates were recorded three days after application. For ovicidal assay, ten adult females were transferred to each leaf disc $(25 \mathrm{~mm})$ and incubated at $25^{\circ} \mathrm{C}$. After $24 \mathrm{~h}$, females were removed and leaf discs carrying eggs were immersed crude extract and in ethanol in case of control. Three discs were made for each concentration and control. Number of unhatched eggs was recorded after all eggs on control hatched. 


\section{Data Analysis}

Mortality rates were corrected according to Abbott`s formula (Abbott, 1925).

Corrected mortality $=\frac{\mathrm{T}-\mathrm{C}}{100-\mathrm{C}} \times 100$

Where: $\mathrm{T}=$ dead mites in treatment, $\mathrm{C}=$ dead mites in control.

One-way ANOVA $(P<0.05)$ was used. Means were compared by Duncan's test (Duncan, 1955).

\section{RESULTS AND DISCUSSION}

\section{Isolation of Entomopathogenic Fungi}

Isolation by insect bait method using larvae of wax moth Galleria mellonella was carried out in the collected soil samples. Dead larvae from seven soil samples out of seventeen showed fungal growth. Three Penicillium, five Aspergillus and two Fusarium isolates were isolated, while only one entomogenous Purpureocillium lilacinum isolate were obtained as shown in table (1). Similarly, Barra et al. (2013), isolated thirty-five Paecilomyces lilacinus isolates by means of insect baiting method using the flour beetle Tribolium confusum (Jacquelin du Val), in addition to other fungal genera like Penicillium and Fusarium were also recovered along with Paecilomyces. Since Fungi in the genera Mucor, Penicillium sp., Aspergillus sp., and some others, were usually present as common opportunistic contaminants (Gouli et al., 2013). Vänninen (1996) recovered a number of entomogenous fungi (Metarhizium anisopliae, Beauveria bassiana, Paecilomyces farinosus and P. fumosoroseus) from agricultural soil in Finland by insect bait method.

Table (1). Fungal isolates obtained by insect bait method.

\begin{tabular}{ll}
\hline Cultivated crop & Fungal isolates \\
\hline Eggplant & Aspergillus $s p$. \\
& Fusarium $s p$. \\
\hline Banana & Aspergillus $s p$. \\
\hline Grape & Paecilomyces $s p$. \\
& Fusarium $s p$. \\
\hline Mango & Aspergillus $s p$. \\
\hline Eggplant & Penicillium $s p$. \\
\hline Sweet pepper & Penicillium $s p$. \\
& Aspergillus $s p$. \\
\hline Tomato & Aspergillus $s p$. \\
& Penicillium $s p$. \\
\hline
\end{tabular}

Egyptian J. Desert Res., 68, No. 2, 157-172 (2018) 


\section{Acaricidal Potency of Purpureocillium lilacinum on T. urticae}

Evaluation of the obtained entomopathogenic isolate against adult females of $T$. urticae showed high acricidal potency, in which the fungal hyphae emerged from cadavers of T. urticae (Fig. 2). Results in table (2) showed concentration-dependant effectiveness. The highest mortality rates exhibited by concentration of $1.6 \times 10^{8}$ conidia/ml $(77.97 \%)$ on day 10 however; there is no significant difference with the mortality percent exhibited by $5 \times 10^{7}$ conidia/ml $(71.19 \%)$ after the same time. Median lethal concentration of $P$. lilacinum is $2.85 \times 10^{6}$ conidia/ml (Fig. 3), which was lower than values obtained by some Metarhizium anisopliae and Beauveria bassiana isolates that ranged between $0.7 \times 10^{7}$ and $2.5 \times 10^{7}$ conidia/ml (Wekesa et al., 2005). Similar results were demonstrated by Sanjaya et al. (2015), that showed the acricidal potency of P. lilcainus with mortality of $70 \%$ in concentration of $10^{7}$, while in $10^{8}$ was $74.44 \%$ on T. kanzawai. Shin et al. (2017) reported that $P$. lilacinum achieved $84 \%$ mortality on T. urticae. Shin et al. (2011) investigated the effect of P. lilacinus on T. urticae using SD tower sprayer in application of conidial suspension that killed $73 \%$ of tested population after 6 days from application. Whereas, the results illustrated in the current investigation is higher than that caused by four Beauveria bassiana isolates studied by Topuz et al. (2016), since the highest mortality exhibited on adults of T. cinnabarinus was $50 \%$ with concentration of $10^{7}$ conidia/ml after 10 days. However, the results obtained in the current study may be less in comparison with mortality rates achieved in some of the previously mentioned reports; this may be because the conidial suspension was applied with spray method while we used the treated food method in the present bioassay. Geroh et al. (2015) supported this conclusion as they found that the direct spray method showed less $\mathrm{LC}_{50}$ and $\mathrm{LT}_{50}$ than the treated food method.

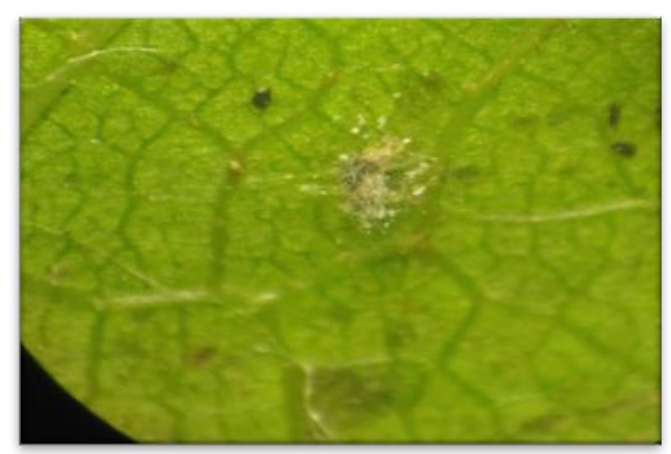

Fig. (2). Hyphae of P. lilcinum emerging from dead cadaver of T. urticae adult female as shown under dissecting microscope.

Egyptian J. Desert Res., 68, No. 2, 157-172 (2018) 
Table (2). Mortality rates of adult females of $T$. urticae after 7 and 10 days after application.

\begin{tabular}{lcccc}
\hline & \multicolumn{2}{c}{$\begin{array}{c}\text { Mortality \% } \\
\text { after 7 days }\end{array}$} & \multicolumn{2}{c}{$\begin{array}{c}\text { Mortality \% } \\
\text { after 10 days }\end{array}$} \\
\hline Conc. & $\begin{array}{c}\text { Dead females } \\
(\text { mean } \pm \text { SE) }\end{array}$ & $\begin{array}{c}\text { Corrected } \\
\text { mortality } \\
(\%)\end{array}$ & $\begin{array}{c}\text { Dead females } \\
(\text { mean } \pm \text { SE) }\end{array}$ & $\begin{array}{c}\text { Corrected } \\
\text { mortality } \\
(\%)\end{array}$ \\
\hline Control & $1.00^{\mathbf{c}} \pm 0.58$ & 0.0 & $1.67^{\mathrm{d}} \pm 0.67$ & 0.0 \\
$8 \times 10^{5}$ & $2.00^{\mathbf{c}} \pm 0.58$ & 10.10 & $5.00^{\mathbf{c}} \pm 0.58$ & 33.90 \\
$2.6 \times 10^{6}$ & $4.67^{\mathbf{b}} \pm 0.33$ & 37.04 & $7.33^{\mathbf{b}} \pm 0.33$ & 57.63 \\
$5 \times 10^{7}$ & $6.67^{\mathbf{a}} \pm 0.88$ & 57.24 & $8.67^{\mathbf{a b}} \pm 0.67$ & 71.19 \\
$1.6 \times 10^{8}$ & $7.67^{\mathbf{a}} \pm 0.33$ & 67.34 & $9.33^{\mathbf{a}} \pm 0.33$ & 77.97 \\
\hline
\end{tabular}

Values are mean no. of dead mite individuals \pm standard error of three replicates.

Different letters in the same column indicate a significant difference according to Duncan's multiple range test.

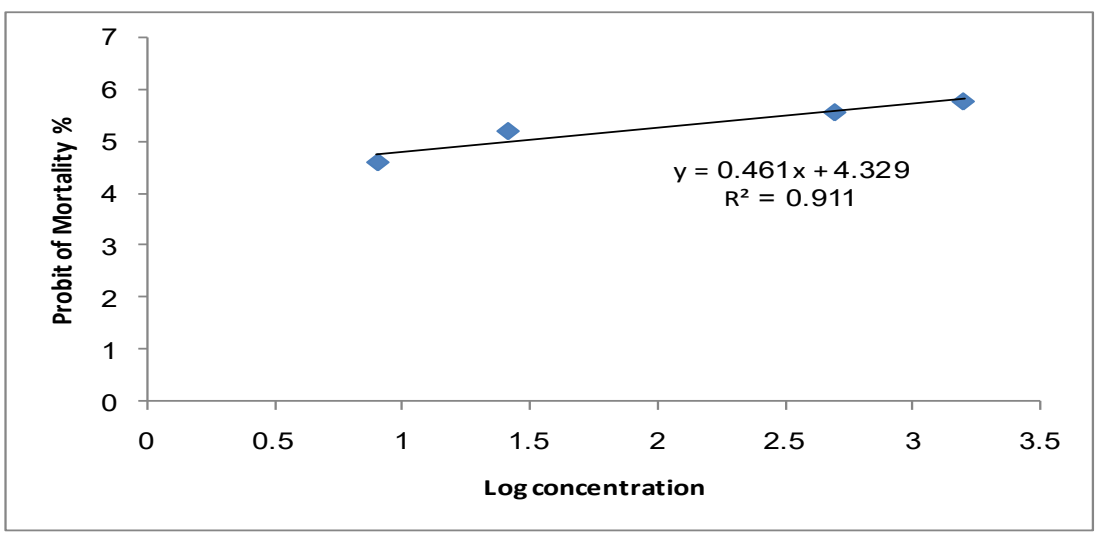

Fig. (3). Lethal concentration of $P$. lilacinum and mortality rate of adult females of T. urticae.

\section{Identification of the Entomogenous Fungus}

Colonies on MEA were growing fast, with a diameter of $25-35 \mathrm{~mm}$ after 7 days at $25^{\circ} \mathrm{C}$. It consists of a basal felt with or without floccose aerial overgrowth as shown in fig. (4). Colonies were white at first, turns to vinaceous with purpleor reverse. Conidiophores were emerged from submerged hyphae with length of 4-6 $\mu \mathrm{m}$. Whorls of 2-4 phialides are Egyptian J. Desert Res., 68, No. 2, 157-172 (2018) 
carried on verticillate branches. Phialides consist of a swollen basal part tapering into a short distinctive neck (about $1 \mu \mathrm{m}$ wide). Conidia are in divergent chains, they were ellipsoidal to fusiform in shape. The conidia (2$3 \times 2-4 \mu \mathrm{m})$ were smooth-walled to slightly roughened, hyaline, purple en masse (Luangsa-ard et al., 2011).
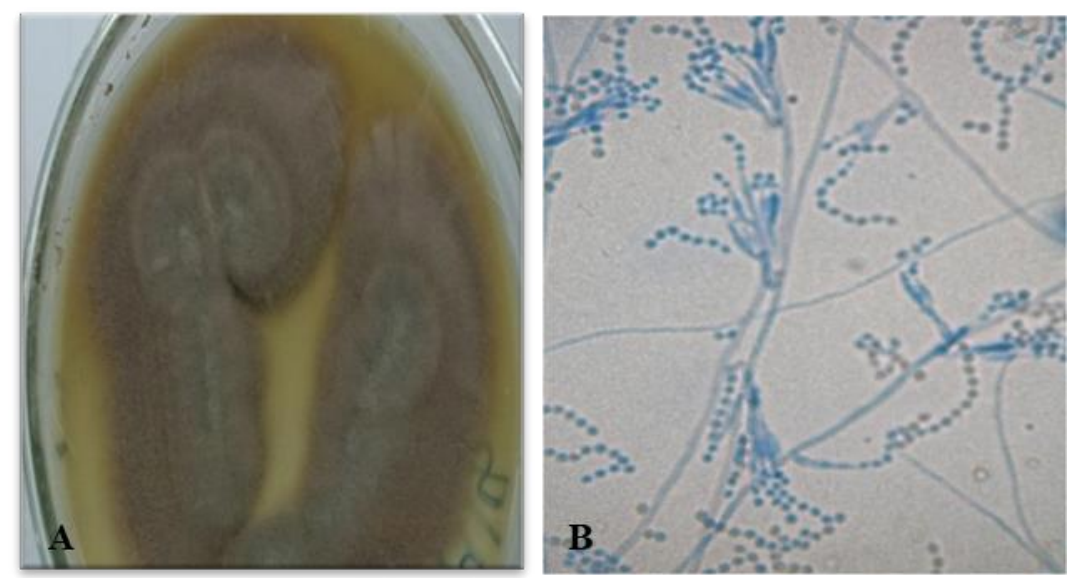

Fig. (4). P. lilacinum A. on PDA media, B. under light microscope (40X) showing it`s phialides and conidia.

\section{Chitinolytic and Proteolytic Activity of P. lilacinum}

Conidial adhesion, germination rate and growth on the insect integument influence the virulence of entomopathogenic fungi (Barra et al., 2015). The pathogenicity of entomopathogenic fungi is determined by its proteolytic and chitinolytic activity (Mondal et al., 2016). Thus, the development of effective fungal agents used for insect biological control would require studying the fungal enzyme activities involved in penetration of insect cuticle (Scorsetti et al., 2011). On the other hand, some studies showed no relationship between the fungal pathogenicity and its enzyme activity (Rosato et al., 1981). In the current investigation, the chitinolytic activity of the obtained $P$. lilacinum strain was weak in comparison with its proteolytic activity, as shown in fig. (5). Since chitinolytic activity showed a small halo sized $3.33 \mathrm{~mm}$ in diameter (after 5 days), $4.36 \mathrm{~mm}$ (after 7 days) and $4.43 \mathrm{~mm}$ in diameter (after 10 days). Obviously the chitinolytic activity of $P$. lilacinum increased over time but with insignificant rate. However, the proteolytic activity was strong since, the clear zone obtained was $20.2 \mathrm{~mm}$ (after 5 days), $22.6 \mathrm{~mm}$ (after 7 days) and $25.8 \mathrm{~mm}$ (after 10 days). The difference between the proteolytic activity after 5 days and 7 days was insignificant. The high proteolytic activity of $P$. lilacinum isolate may contribute in its high virulence against $T$. urticae. In view of the fact that protease enzymes are considered as the most important within the infection 
process (Mustafa and Kaur, 2009) because proteins are the major component in the exoskeleton of insects (61-70\%) (Hepburn, 1985). Once the epicuticle breaks down, the fungus produces large amounts of proteases that enable it to degrade proteins in insect cuticle and use the released amino acids as nutrients (Wang et al., 2002 and de Carolina Sánchez-Pérez et al., 2014). Despite, the weak chitinolytic activity of the obtained P. lilacinum isolate, its virulence against $T$. urticae was relatively high which may be due to the soft bodies of T. urticae. Since it, unlike insect pests, lacks hard integument. Similarly, Castellanos-Moguel et al. (2008) found that the protease activity of both of the most virulent $P$. fumosoroseus isolates against T. vaporariorum reached its peak after $120 \mathrm{~h}$ while the chitinase activity was maximum at 264 and $312 \mathrm{~h}$.

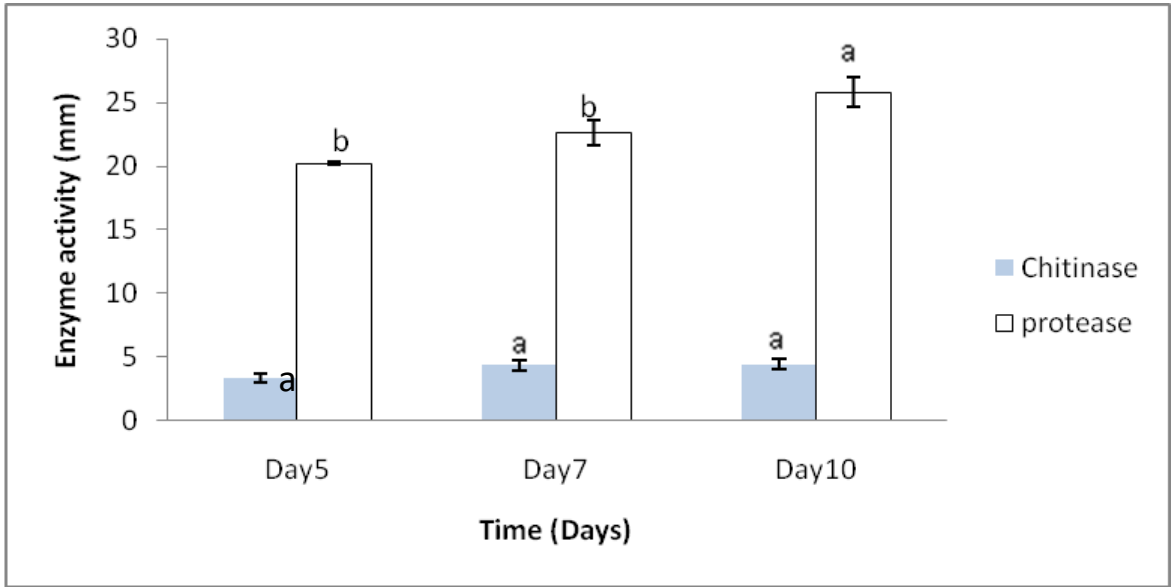

Fig. (5). Activity of chitinase and protease enzymes produced by $P$. lilacinum.

Data are presented as the mean value (diameter of clear zone in $\mathrm{mm}$ ) \pm SE. Error bars are corresponding to standard error. ${ }^{\mathrm{a}, \mathrm{b}}$ Different letters indicate a significant difference according to Duncan's multiple range test.

\section{Effect of Crude Extract of $P$. lilacinum on Adult Females and Eggs of T. urticae}

Secondary metabolites of entomopathogenic fungi show insecticidal or antifeedant effect for pests (Kim et al., 2013). Among them, P. lilacinum produce secondary metabolites that show biological control activity against various pests. For instance, extract of $P$. lilacinus shows nematicidal activity against Meloidogyne incognita (Liu et al., 2009). Freed et al. (2012) reported the insecticidal activity of $P$. lilacinus protein extract that showed mortality rate of $45.83 \%$ against larvae of Plutella xylostella (the diamond back moth). In this context, the current investigation revealed the acaricidal potency of $P$. lilacinum. Data from fig. (6) show that the crude extract of $P$. 
lilacinum exhibits more toxic effect on eggs than adult females of T. urticae. Concentration of $30 \mathrm{mg} / \mathrm{ml}$ showed the highest mortality rate of $58.33 \%$ on adults and $95.96 \%$ on eggs, followed by 20,10 and $5 \mathrm{mg} / \mathrm{ml}$ that caused $26.67,5$ and $3.33 \%$ on adult, respectively, and $82.49,40.40$ and $15.15 \%$ on eggs, respectively. $\mathrm{LC}_{50}$ value exhibited by crude extract of $P$. lilacinum is $10.49 \mathrm{mg} / \mathrm{ml}$ for eggs and $30.75 \mathrm{mg} / \mathrm{ml}$ for adults. Similarly, the acaricidal effect of secondary metabolites produced by entomopathogenic fungi is reported in some studies. For instance, the culture filtrate of Hirsutella thompsonii exhibited mortality rate of $55.90 \%$ on T. urticae and citrus rust mite, Phyllocoptruta oleivora (Aghajanzadeh et al., 2006), the crude extract of Hypocrella raciborskii showed residual toxicity of $80 \%$ on T. urticae (Buttachon and Kijjoa, 2013) and the culture filtrate of B. bassiana and M. anisoplae highly reduced mite population (Yun et al., 2017).

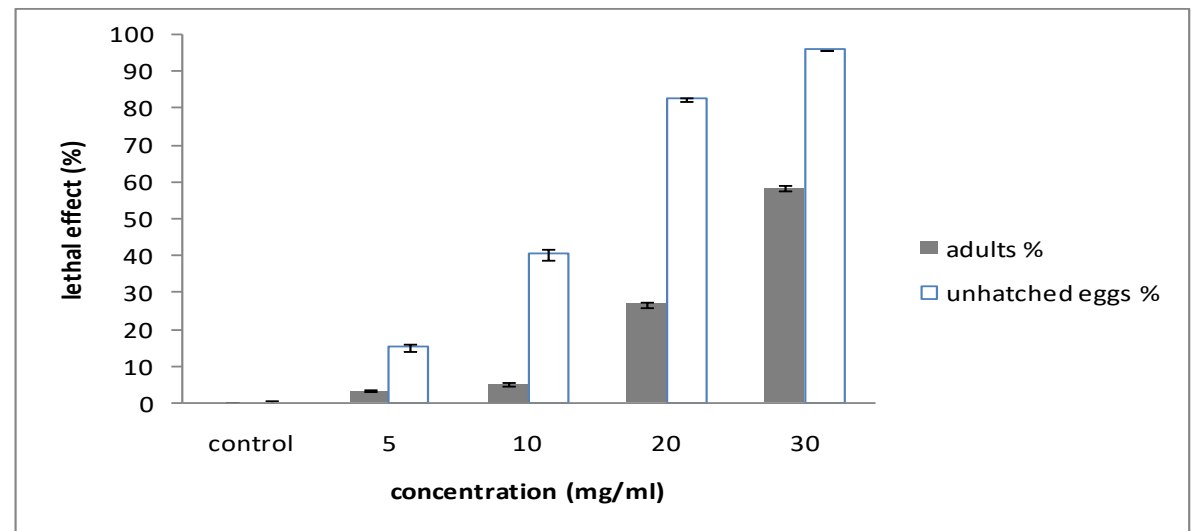

Fig. (6). Effect of crude extract of $P$. lilacinum on adult females and eggs of T. urticae.

Error bars are corresponding to SE of the mean value of the dead mite individuals.

\section{CONCLUSION}

In conclusion, A Purpureocillium lilacinum isolate was successfully recovered by insect baiting technique using larvae of wax moth Galleria mellonella. High acaricidal potency has been shown by both the conidia and crude extract of $P$. lilacinum against $T$. urticae. So, $P$. lilacinum could be effectively used as bio-rationale control of spider mites. Nevertheless, further investigations are required to separate active compounds responsible for the acaricidal effect. In addition, compatibility of the obtained isolate with other biocontrol agents should be studied. 


\section{REFERENCES}

Abbott, W.S. (1925). A method of computing the effectiveness of an insecticide. J. Econ. Entomol., 18 (2): 265-267.

Aghajanzadeh, S., B. Mallik and S.C. Chandrashekar (2006). Toxicity of culture filtrate of Hirsutella thompsonii fisher against citrus rust mite, Phyllocoptruta oleivora ashmead (Acari: Eriophyidae) and two spotted spider mite, Tetranychus urticae Koch (Acari: Tetranychidae). Int. J. Agric. Biol., 8 (2): 276-279.

Al-Ahmadi, K.J., M.T. Yazdi, M.F. Najafi, A.R. Shahverdi, M.A. Faramarzi, G. Zarrini and J. Behravan (2008). Optimization of medium and cultivation conditions for chitinase production by the newly isolated: Aeromonas sp. Biotechnology, 7 (2): 266-272.

Attia, S., K.L. Grissa, G. Lognay, E. Bitume, T. Hance and A.C. Mailleux (2013). A review of the major biological approaches to control the worldwide pest Tetranychus urticae (Acari: Tetranychidae) with special reference to natural pesticides. Journal of Pest Science, 86 (3): 361-386.

Barra, P., L. Rosso, A. Nesci and M. Etcheverry (2013). Isolation and identification of entomopathogenic fungi and their evaluation against Tribolium confusum, Sitophilus zeamais, and Rhyzopertha dominica in stored maize. Journal of Pest Science, 86 (2): 217-226.

Barra, P., M. Etcheverry and A. Nesci (2015). Improvement of the insecticidal capacity of two Purpureocillium lilacinum trains against Tribolium confusum. Insects, 6 (1): 206-223.

Buttachon, S. and A. Kijjoa (2013). Acaricidal activity of Hypocrella raciborskii Zimm. (Hypocreales: Clavicipitaceae) crude extract and some pure compounds on Tetranychus urticae Koch (Acari: Tetranychidae). African Journal of Microbiology Research, 7 (7): 577-585.

Castellanos-Moguel, J., R. Cruz-Camarillo, E. Aranda, T. Mier and C. Toriello (2008). Relationship between protease and chitinase activity and the virulence of Paecilomyces fumosoroseus in Trialeurodes vaporariorum (Hemiptera: Aleyrodidae). Revista Mexicana de Micología, 28: 71-80.

Chandler, D., G. Davidson, J.K. Pell, B.V. Ball, K. Shaw and K.D. Sunderland (2000). Fungal biocontrol of Acari. Biocontrol Science and Technology, 10 (4): 357-384.

Choi, W., S.G. Lee, H.M. Park and Y.J. Ahn (2004). Toxicity of plant essential oils to Tetranychus urticae (Acari: Tetranychidae) and Phytoseiulus persimilis (Acari: Phytoseiidae). Journal of Economic Entomology, 97: 553-558.

De Carolina Sánchez-Pérez, L., J.E. Barranco-Florido, S. RodríguezNavarro, J.F. Cervantes-Mayagoitia and M.Á. Ramos-López (2014).

Egyptian J. Desert Res., 68, No. 2, 157-172 (2018) 
Enzymes of entomopathogenic fungi, advances and insights. Advances in Enzyme Research, 2 (02): 65.

Duncan, D.B. (1955). Multiple range and multiple F-tests. Biometrics, 11 (1): $1-42$.

Fasulo, T.R. and H.A. Denmark (2000). Two spotted spider mite, Tetranychus urticae Koch (Arachnida: Acari: Tetranychidae). University of Florida Cooperative Extension Service, Institute of Food and Agricultural Sciences, EDIS.

Freed, S., J. Feng-Liang, M. Naeem, R. Shun-Xiang and M. Hussian (2012). Toxicity of proteins secreted by entomopathogenic fungi against Plutella xylostella (Lepidoptera: Plutellidae). International Journal of Agriculture and Biology, 14 (2): 291-295.

Gatarayiha, M.C. (2010). Biological control of the two-spotted spider mite, Tetranychus urticae Koch (Acari: tetranychidae). Ph.D. Thesis, University of KwaZulu-Natal, Pietermaritzburg, South Africa.

Geroh, M., R. Gulati and K. Tehri (2015). Determination of lethal concentration and lethal time of entomopathogen Beauveria bassiana (Balsamo) Vuillemin against Tetranychus urticae Koch. International Journal of Agriculture Sciences, 7 (5): 523-528.

Gouli, V., S. Gouli, J.A. Marcelino, M. Skinner and B.L. Parker (2013). Entomopathogenic fungi associated with exotic invasive insect pests in Northeastern forests of the USA. Insects, 4 (4): 631-645.

Hasan, S., A. Ahmad, A. Purwar, N. Khan, R. Kundan and G. Gupta (2013). Production of extracellular enzymes in the entomopathogenic fungus Verticillium lecanii. Bioinformation, 9 (5): 238.

Hawksworth, D.L., P.M. Kirk, B.C. Sutton and D.N. Pegler (1995). Ainsworth and Bisby's. Dictionary of the Fungi, $8^{\text {th }}$ Ed., CAB International, Wallingford, UK, $616 \mathrm{pp}$.

Hepburn, H.R. (1985). Structure of the Integument in "Comprehensive Insect Physiology, Biochemistry and Pharmacology" (Kerkut, G.A. and L.I. Gilbert eds.) Pergamon, Oxford.

Kapsoot, E., M. Mwangi and A. Kamau (2013). Repellence and toxicity effect of crude plant extracts on the two-spotted spider mite Tetranychus urticae on Roses. International Symposium on Ornamentals in Africa, 1077: 155-164.

Kim, J.J., G.Y. Jeong, J.H. Han and S.Y. Lee (2013). Biological control of Aphid using fungal culture and culture filtrates of Beauveria bassiana. Mycobiology, 41: 221-224.

Kuddus, M. and I.Z. Ahmad (2013). Isolation of novel chitinolytic bacteria and production optimization of extracellular chitinase. Journal of Genetic Engineering and Biotechnology, 11 (1): 39-46.

Liu, Y.J., C.Y. Zhai, Y. Liu and K.Q. Zhang (2009). Nematicidal activity of Paecilomyces spp. and isolation of a novel active compound. The Journal of Microbiology, 47 (3): 248-252.

Egyptian J. Desert Res., 68, No. 2, 157-172 (2018) 
Luangsa-ard, J., J. Houbraken, T. van Doorn, S.B. Hong, A.M. Borman, N.L. Hywel-Jones and R.A. Samson (2011). Purpureocillium, a new genus for the medically important Paecilomyces lilacinus. FEMS Microbiology Letters, 321 (2): 141-149.

Maniania, N.K., D.M. Bugeme, V.W.Wekesa, I. Delalibera and M. Knapp (2008). Role of Entomopathogenic Fungi in the Control of Tetranychus evansi and Tetranychus urticae (Acari: Tetranychidae), Pests of Horticultural Crops. In "Diseases of Mites and Ticks". Springer, Dordrecht, p. 259-274.

Mondal, S., S. Baksi, A. Koris and G. Vatai (2016). Journey of enzymes in entomopathogenic fungi. Pacific Science Review A: Natural Science and Engineering, 18 (2): 85-99.

Mustafa, U. and G. Kaur (2009). Extracellular enzyme production in Metarhizium anisopliae isolates. Folia Microbiologica, 54: 499-504.

Neal, Jr. J.W., R.K. Lindquist, K.M. Gott, and M.L. Casey (1987) Activity of the thermostable p-exotoxin of Bacillus thuringiensis Berliner on Tetranychus urticae and T. cinnabarinus. Journal of Agricultural Entomology, 4 (1): 33-40.

Putter, I., J.G. Mac Connell, F.A. Preiser, A.A. Haidri, S.S. Ristich and R.A. Dybas (1981). Avermectins: novel insecticides, acaricides and nematicides from a soil microorganism. Experientia, 37 (9): 963964.

Roberts, W.K. and C.P. Selitrennikoff (1988). Plant and bacterial chitinases differ in antifungal activity. Microbiology, 134 (1): 169-176.

Roobakkumar, A., A. Babu, D.V. Kumar and S. Sarkar (2011). Pseudomonas fluorescens as an efficient entomopathogen against Oligonychus coffeae Nietner (Acari: Tetranychidae) infesting tea. Journal of Entomology and Nematology, 3 (5): 73-77.

Rosato, Y.B., C.L. Messias and J.L. Azevedo (1981). Production of extracellular enzymes by isolates of Metarhizium anisopliae. Journal of Invertebrate Pathology, 38 (1): 1-3.

Sanjaya, Y., V.R. Ocampo and B.L. Caoili (2015). Role of new novel entomopathogenic fungi Paecilomyces lilacinus to mortality and infection process of Tetrancyhus kanzawai (Kishida) (Tetranychidae: Acarina). International Journal of Biosciences, 7 (3): 16-23.

Scorsetti, A.C., L.A. Elíades, S.A. Stenglein, M.N. Cabello, S.A. Pelizza and M.C.N. Saparrat (2011) Pathogenic and enzyme activities of the entomopathogenic fungus Tolypocladium cylindrosporum (Ascomycota: Hypocreales) from Tierra del Fuego, Argentina. Rev. Biol. Trop., 60: 833-841.

Shin, T.Y., W.W. Lee, S.H. Ko, Z. Ji, D.H. Shin, K.H. Son and S.D. Woo (2011) Preliminary evaluation of Paecilomyces lilacinus HY-4 to

Egyptian J. Desert Res., 68, No. 2, 157-172 (2018) 
control Tetranychus urticae. International Journal of Industrial Entomology, 22 (1): 25-28.

Shin, T.Y., S.M. Bae, D.J. Kim, H.G. Yun and S.D. Woo (2017). Evaluation of virulence, tolerance to environmental factors and antimicrobial activities of entomopathogenic fungi against two-spotted spider mite, Tetranychus urticae. Mycoscience, 58 (3): 204-212.

Smith, M. (1996). In "Mite Pests and their Predators on Cultivated Plants in Southern Africa: Vegetables and Berries". Plant Protection Research Institute, Pretoria, South Africa, 90 pp.

Topuz, E., F. Erler and E. Gumrukcu (2016). Survey of indigenous entomopathogenic fungi and evaluation of their pathogenicity against the carmine spider mite, Tetranychus cinnabarinus (Boisd.), and the whitefly, Bemisia tabaci (Genn.) biotype B. Pest Management Science, 72 (12): 2273-2279.

Van Leeuwen, T., J. Vontas, A. Tsagkarakou, W. Dermauw and L. Tirry (2010). Acaricide resistance mechanisms in the two-spotted spider mite Tetranychus urticae and other important Acari: a review. Insect Biochemistry and Molecular Biology, 40 (8): 563-572.

Vänninen, I. (1996). Distribution and occurrence of four entomopathogenic fungi in Finland: effect of geographical location, habitat type and soil type. Mycological Research, 100 (1): 93-101.

Vargas Mesina, R.R. (1993). Thuringiensin toxicity to Tetranychus urticae Koch and Panonychus ulmi (Koch) (Tetranychidae) and effects on cuticle development of immature stages of T. urticae. Ph.D. Thesis, Lincoln University, New Zealand.

Wang, C., M.A. Typas and T.M. Butt (2002). Detection and characterization of $\operatorname{Pr} 1$ virulent gene deficiencies in the insect pathogenic fungus Metarhizium anisopliae. FEMS Microbiology Letters, 213: 251-255.

Wekesa, V.W., N.K. Maniania, M. Knapp and H.I. Boga (2005). Pathogenicity of Beauveria bassiana and Metarhizium anisopliae to the tobacco spider mite Tetranychus evansi. Experimental and Applied Acarology, 36 (1-2): 41-50.

$\mathrm{Wu}, \mathrm{Y}$. and X. Liu (1997). Toxicity and biological effect of abamectin on Tetranychus cinnabarinus in lab. Acta Agriculturae BorealiSinica, 12 (1): 108-111.

Yun, H.G., D.J. Kim, J.H. Lee, J.I. Ma, W.S. Gwak and S.D. Woo (2017). Comparative evaluation of Conidia, Blastospores and culture filtrates from entomopathogenic fungi against Tetranychus urticae. International Journal of Industrial Entomology, 35 (1): 58-62.

Zimmermann, G. (1986). The Galleria bait method for detection entomopathogenic fungi in soil. J. Appl. Entomol., 102: 213-215. 


\section{تقييم النشاط الإبادي لفطر البريبيوسيليوم ليلاسينوم المعزول من التربة الئية المصرية ضد العنكبوت الأحمر ذو البقعتين}

حفحا عادل نوار'، أماني أبو النصر عواد"، عبد الناصر أحمد قبيصي' وجهيزة أحمد

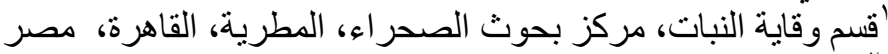

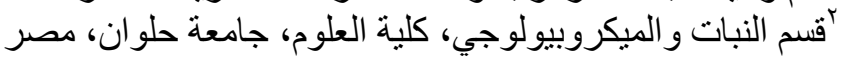

نستهدف هذه الدراسة عزل وتتقية عزلة فطرية ممرضة للحشرات من البيئة المصرية

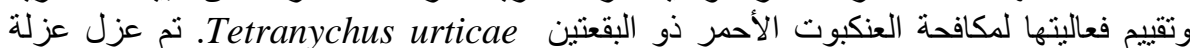

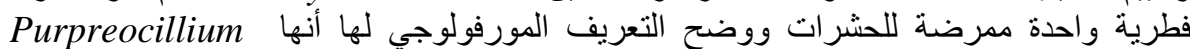

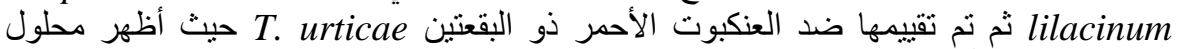

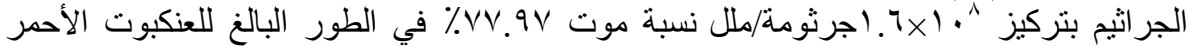

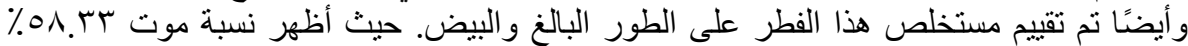

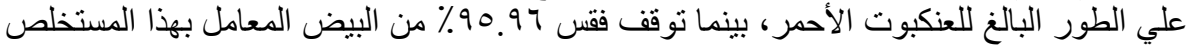

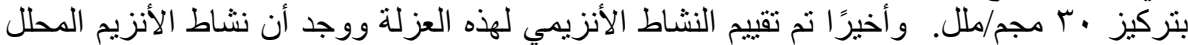

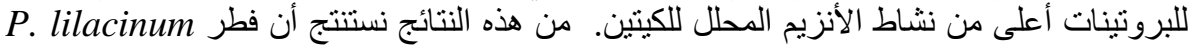
له فعالية عالية ضد العنكبوت الأحمر ذو البقتنين ويمكن أن بستخدم في المقاومة الحيوية لهذه الآفة. 